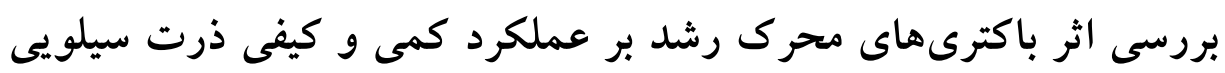

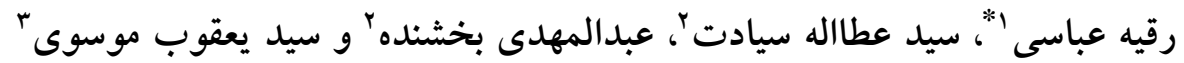

(تاريخ دريافت:

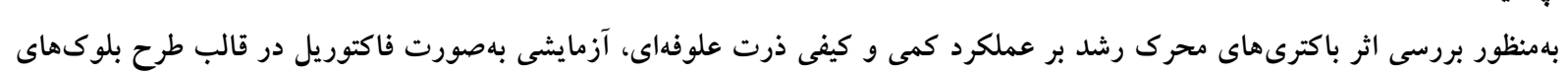

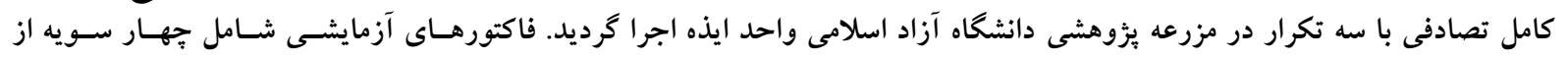

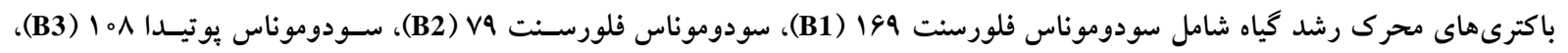

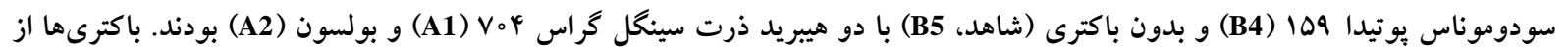

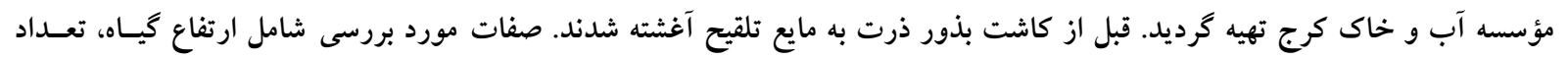

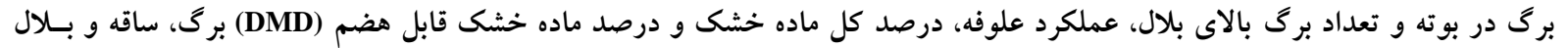

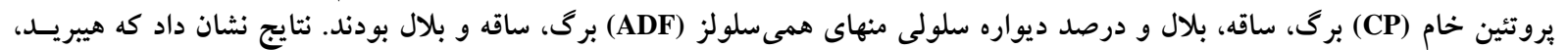

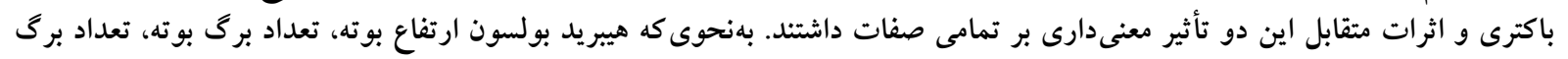

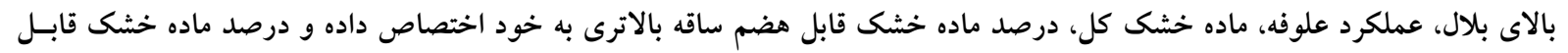

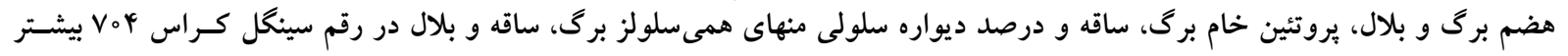

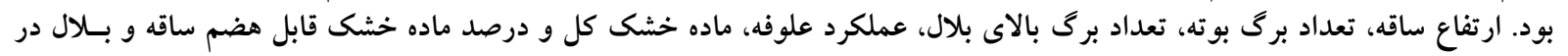

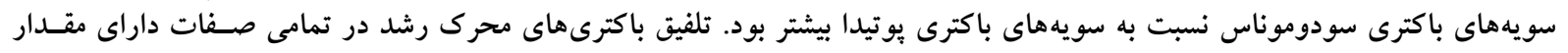

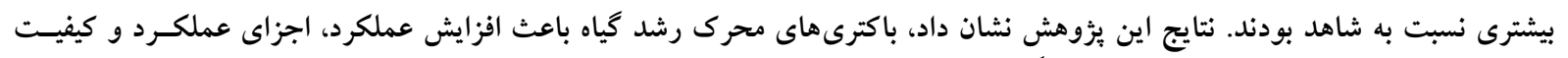

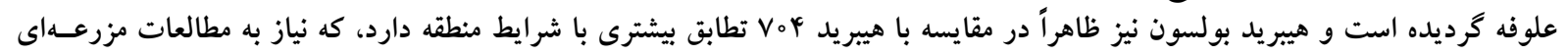

$$
\text { بيشتر دارد. }
$$

وازمهاى كليدى: ذرت، باكترى محرك رشد، ماده خشى قابل هضم، عملكرد

\footnotetext{
ا و r. بهترتيب دانشآموخته كارشناسى ارشد و استادان كروه زراعت، دانشخاه كشاورزى و منابع طبيعى رامين، اهواز r. دكترى زراعت، سازمان جهاد كشاورزى خوزستان، اهواز

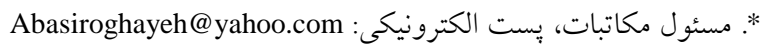


آن بــا بـاكترىهــاى ازتوبــاكتر و ســودوموناس فلورســت

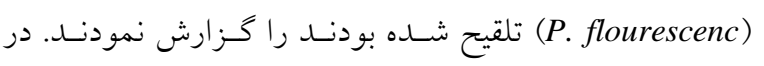

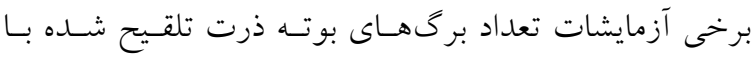

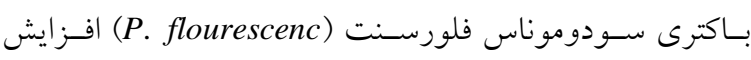

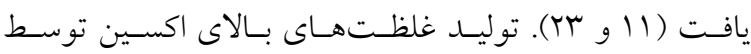
سـودوموناس فلورسـنت يـك خصوصسيت كلسى بـــاى ايسن باكترىها است. اصغر و همكاران (广) با مطالعه توليـد اكسين

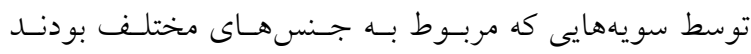

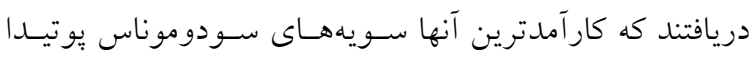

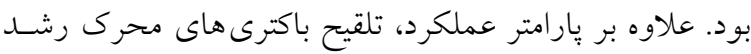

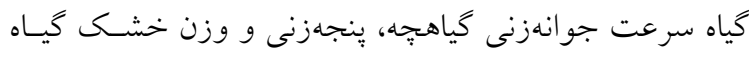

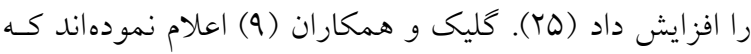

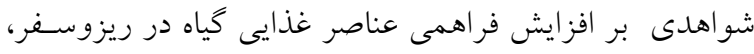

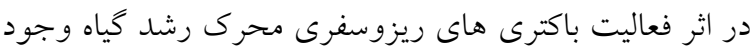

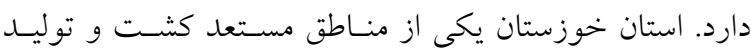
ذرت مى باشد. نظر به اهميت توسعه دامـدارىهـاى صـنعتى



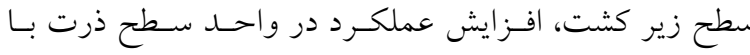

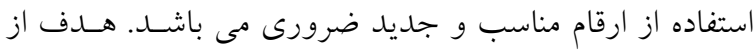
انجام يزوهش حاضر مطالعه اثرات باكترى هاى محـرى رشــــ

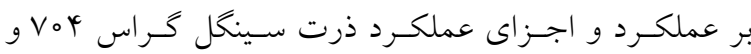

$$
\text { بولسون مىباشد. }
$$

\section{مواد و روش ها - ماد}

اين يزوهش در تابستان ه1/1 در مزرعه تحقيقاتى دانشگاه آزاد

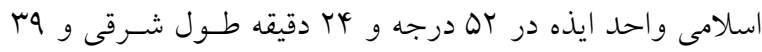
درجه هب دقيقه عرضى شمالى با م10متر ارتفاع ازسطح دريـا بهصورت فاكتوريل در قالب طرح بلوكهاى كامل تصـادفى بـا بـا سه تكرار اجرا كرديد. براى مشخص شدن خــواص فيزيكسى و شيميايى خاك ييش از عمليات اجرايى نمونهبردارى و تجربه و

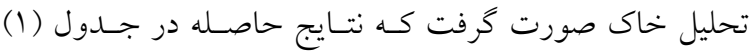

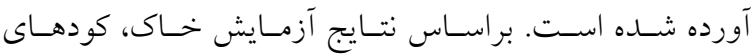

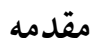

با توجه بـه افـزايش جمعيـت و تقاضـاى روز افـزون بـراى مـواد

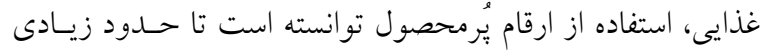

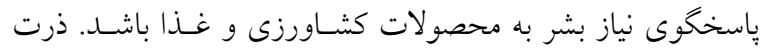

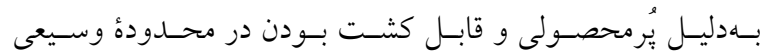

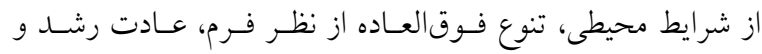

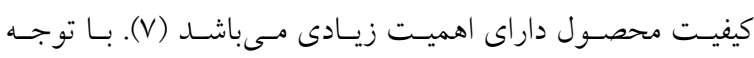
به روند رو به رشد مصرف كودهاى شيميايى در بخش كشـاورزى

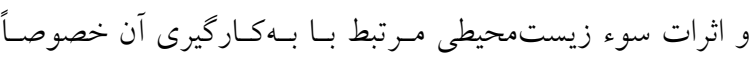

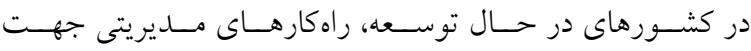

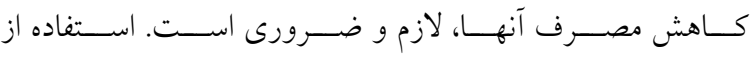

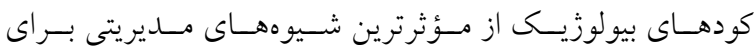
حفظ كيفيت خاك در سطح مطلوب محسوب مسى گردنـد. كاربرد

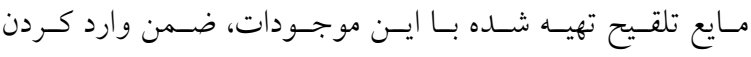

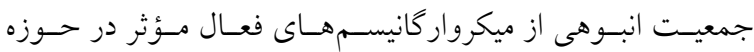

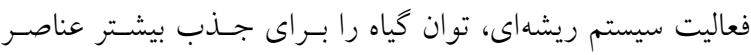

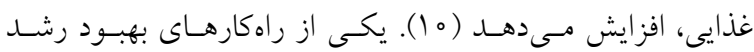

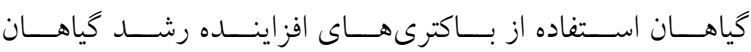
يا Plant growth promoting rhizobacteria) موجب افزايش رشد و عملكرد كياهان مهم زراعى مىشوند (1).

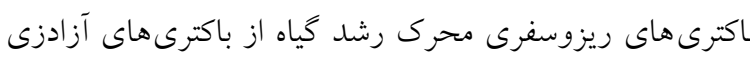

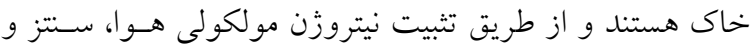
توليد سيدروفورهاى كميلكس كننده آهن، توليد هورمونهـاى

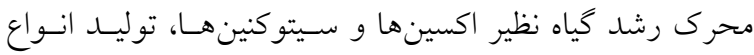
ويتامينها، انحلال تركيبات معلنى فسفاتها، يتاسيم و عناصـر كممصرف، ايجاد رقابت با عوامل بيماريزاى كياهى بـهـواسطه

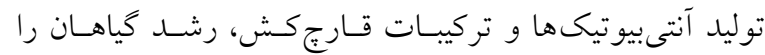

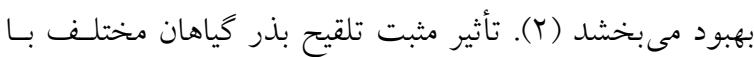
باكترى هاى محرى رشد كياه بر جنبههاى مختلـف رشـــونمو آنها، از جمله قابليت جوانهزنى بذر و بنيه كياهيهـه بررسى و و

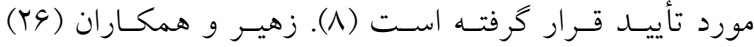

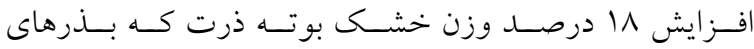


خشى قابل هضم. خشك كردن نمونهــا در آون بـا دمـاى VD درجه سانتى كراد بهمدت لمات ماعت انجام شد و وزن خشك هر يكى از اجزاء و در نهايت وزن خشك علوفـه در هكتـار تعيسين

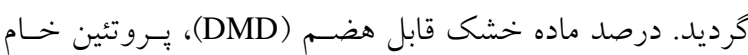

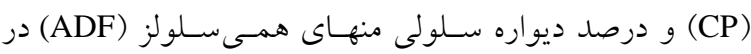

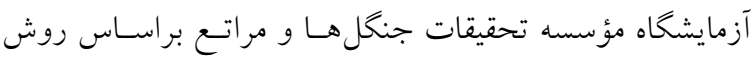
Perten رائه شده توسط جعفرى و همكاران (YI) و با دستخاه مدل Inframatic I I انجام شد. تجزيه واريانس كليه صـفات مـورد بررسى بـا استفاده از نرمافزار هاى Excel و MSTATC انجام كرفت. مقايسه ميانگين صفات مورد بررسى توسط آزمون هند دامنهاى دانكن در سطح احتمال خطا ا درصد محاسبه كرديد.

\section{نتايج و بحث} ارتفاع بوته با توجه به نتايج حاصل از تجزيه واريانس، اثرات متقابل هيبريد

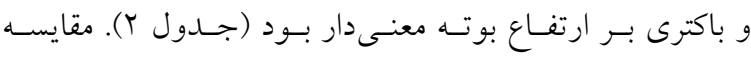

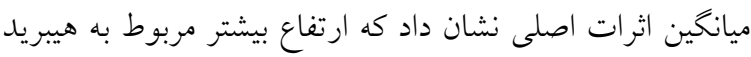

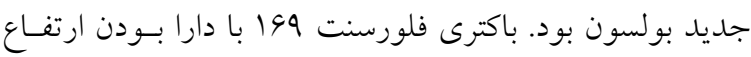

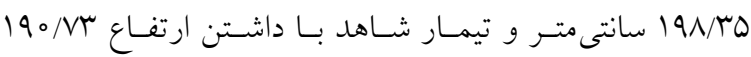

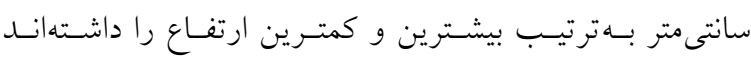
(جدول ؟). مقايسه اثرات متقابل نشان داد كه هيبريـــ بولسـون

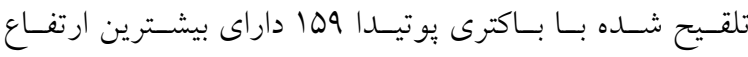
(199/VV)

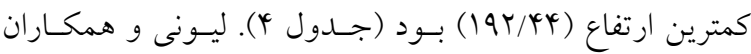

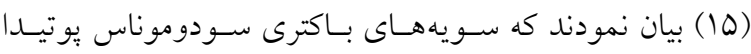
بهدلايلى همجيون توليد هورمونهاى رشد مانـــد اكسين و نيـز

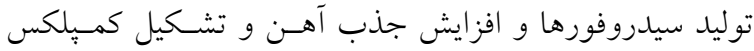

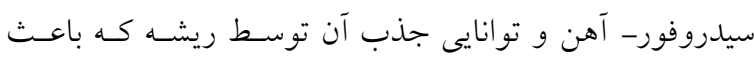

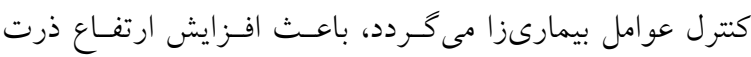

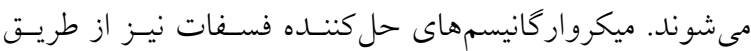

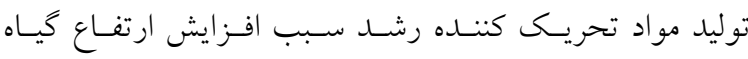

شيميايى بهميزان هـr كيلسوخرم در هكتسار اوره، 010 كيلـوكرم

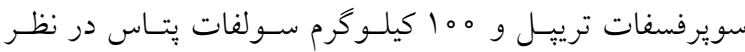

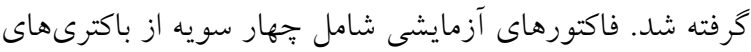

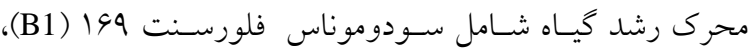

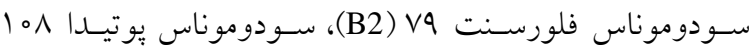

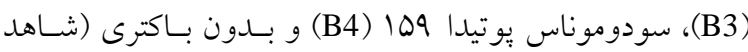

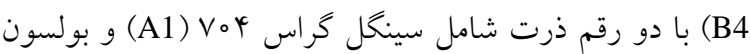

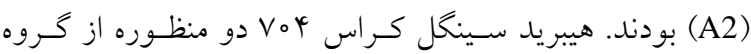
ديررس است و در سطح وسيعى از شرايط آبوهـوايى كشـور

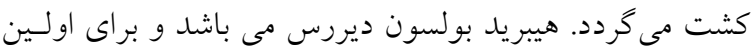
بار تحت عنوان بولسون در سال ومبا توسط بخش كشـاورزى

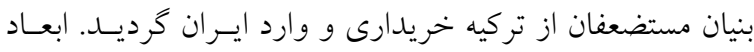

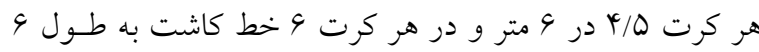
متر و فاصله بين خطوط VD سانتىمتر بود. قبل از كاشت بــــور

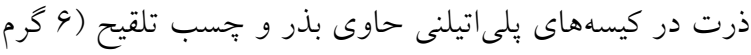

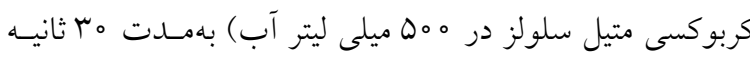

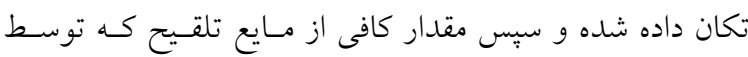

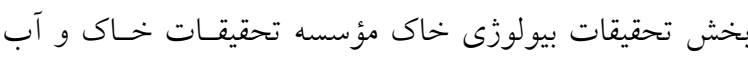
تهيه شد، به آن افزوده شد و بهمدت هץ ثانيه ديخــ تكـان داده

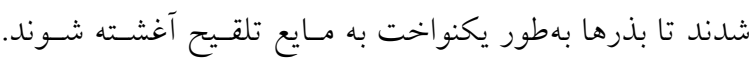
كشت در ها تير ماه صورت گرفت. يكى سوم كود نيتروزن همراه

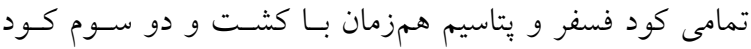



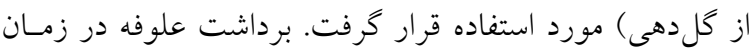

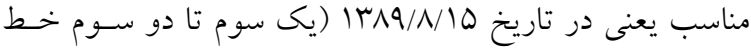
شيرى) صورت گرفت (ها). بوتهها از دو خط ميانى هر كرت لهرت فرعى (خطوط عملكرد) با در نظر گرفتن نيم متر حاشيه از هـر طرف و در مجموع از مساحتى بالغ بر دو مترمربـع بـهصـورت

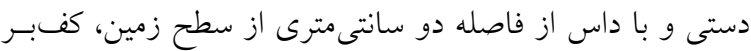

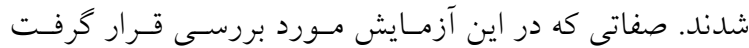

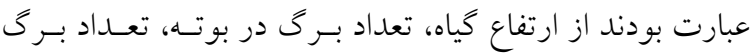
بالاى بلال، عملكرد علوفه، درصد كل ماده خشك و درصد ماده 
جدول ا. ويزَى هاى فيزيكى و شيميايى خاك مورد آزمايش

\begin{tabular}{|c|c|c|c|c|c|c|c|c|}
\hline شورى & يتاسيم & فسفر & نيتروزن كل & مواد آلى & مواد خنثى شونده & \multirow{2}{*}{ لِ بهاش } & \multirow{2}{*}{ بافت خاك } & عمق خاى \\
\hline (دسىزيمنس بر متر) & \multicolumn{2}{|c|}{ (ميلى گرم بر كيلوكرم) } & \multicolumn{3}{|c|}{ (درصد) } & & & (سانتىمتر) \\
\hline$\circ / 1$ & INT & $T V / Q$ &.$/ 11$ & $1 / \circ V$ & ra & $V / 9$ & سيلتى & $0-r_{0}$ \\
\hline
\end{tabular}

هم جنين نقش نيتروزن در افزايش رشد رويشى، مىتوانسـ از

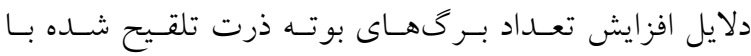

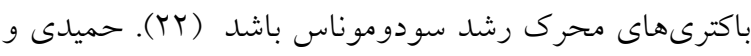

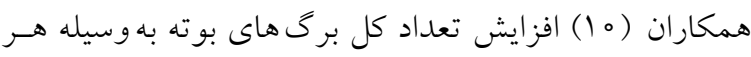
جهار باكترى را سطح يكى درصد معنى دار دانستند.

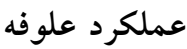
نتايج حاصل از تجزيه واريانس داده ها، نشان داد كـه اثـرات

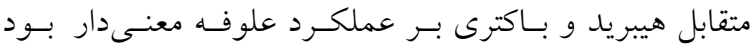

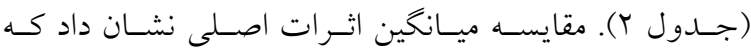
عملكرد بيشتر علوفه مربوط به رقم جديد بولسون با ميانخين

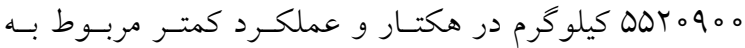

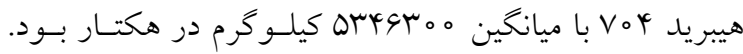

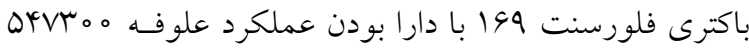

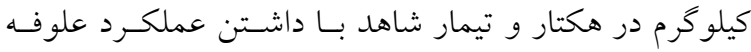

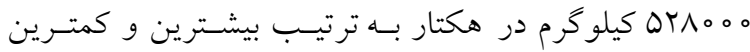

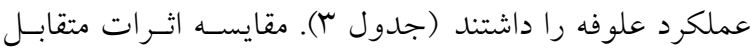

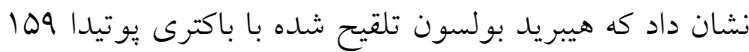

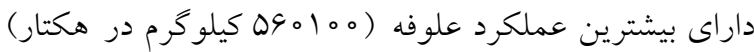

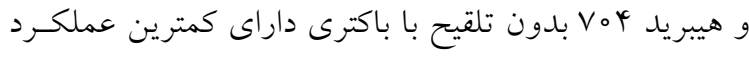

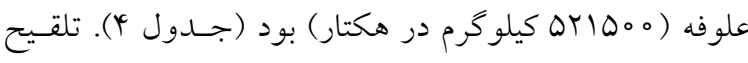

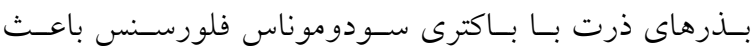

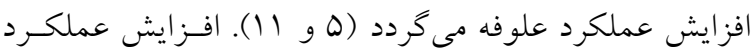

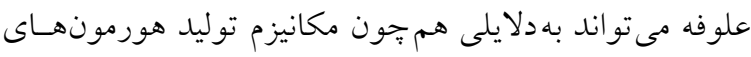

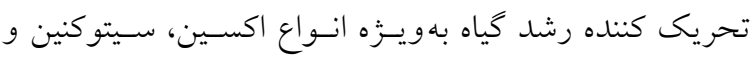

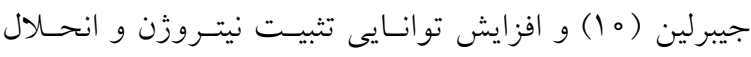

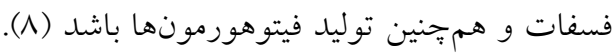

مىشوند. محققان افزايش ارتفاع بوته توسط باكترىهاى محرى

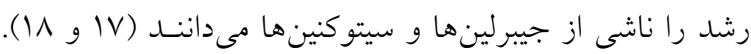

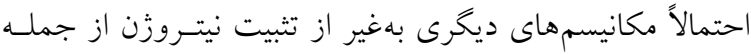
توليد مواد تنظيم كننده رشد، مانند ايندول استيك اسـيد (IAA)

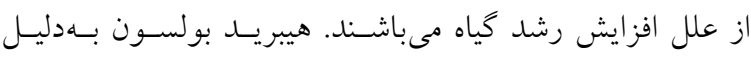

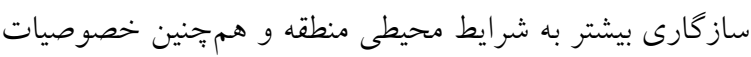

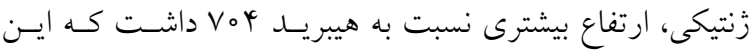
موضوع در نهايت منجر به افزايش نهايى عملكرد علوفه كرديد. بـائ.

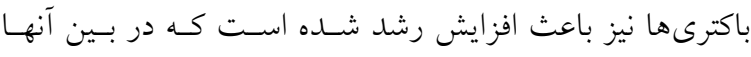

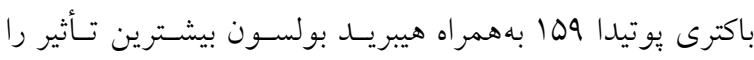

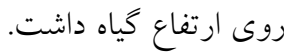

\section{تعداد برى در بوته} با توجه به نتايج حاصل از تجزيـهـ واريـانس، اثـراث متقابـل هيبريد و باكترى بر تعداد برى در بوته معنىدار شد (جــدول Y). مقايسه ميانخين اثرات اصلى نشان داد كه هيبريد بولسون

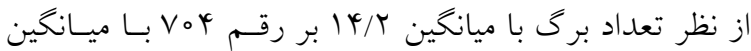

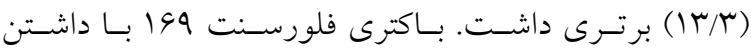

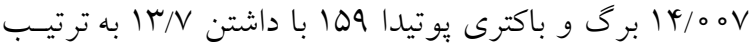
بيشترين و كمترين تعداد برك در كياه را دارا بودند (جــدول r). مقايسه اثرات متقابل نشان داد كه بيشترين تعداد برك در

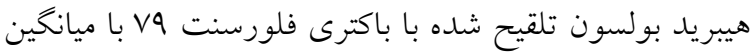

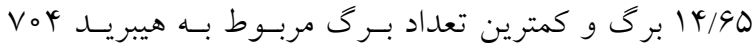

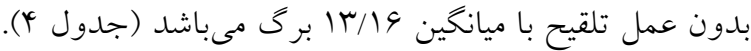

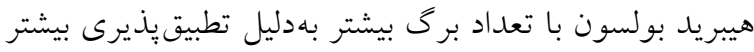
با محيط در نهايت عملكـرد و مـاده خشـك بيشـرى توليسـ

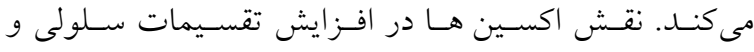



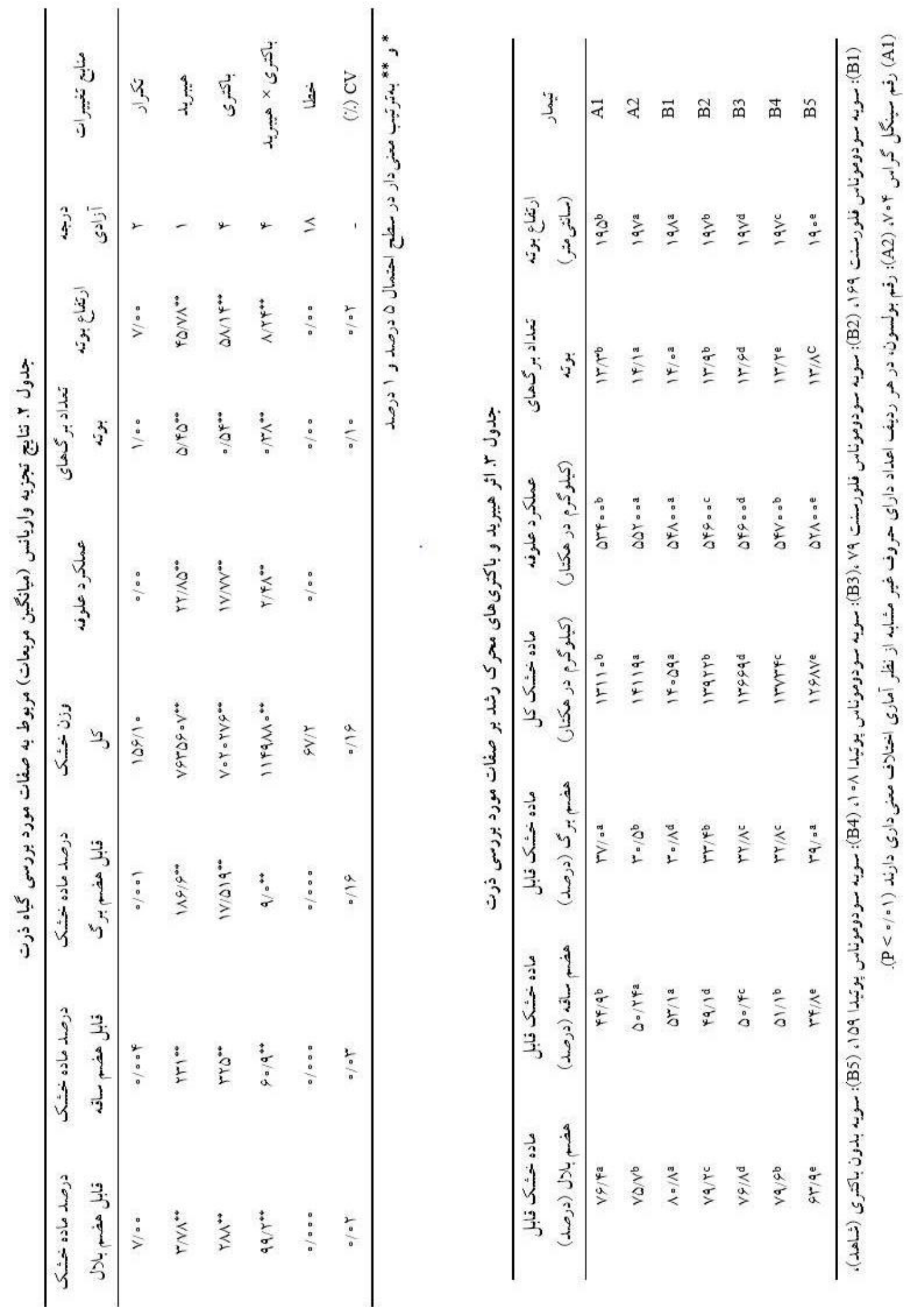
نشريه توليد و فرآورى محصولات زراعى و باغى / سال ششم / شماره بيست و يكم / پاييز ههبا




افزايش سن گياه (بهدليل افزايش ليخنينسى شــن)، تعـداد بـرى

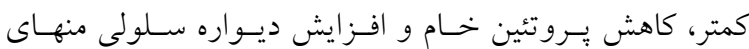

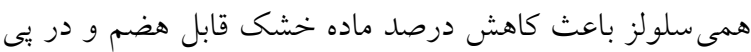
آن كاهش كيفيت علوفه مى شود (19). بركهاى كياه در مقايسه با ساقها از درصد بروتئين بيشتر و درصد الياف كمتر و قابليت

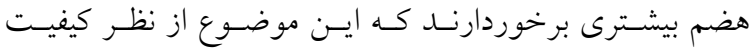
محصول مهم مىباشد (10 و r T درصد). هيبريد بولسون بهدليل

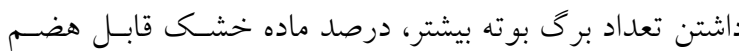

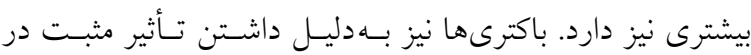

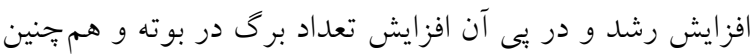
بالا بردن درصد يروتئين، درصـد مـاده خشـى قابـل هضــم را

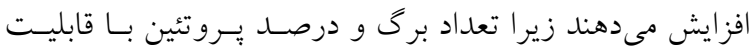
هضم همبستكى مثبت دارد (r).

\section{درصد ماده خشك قابل هضم ساقه} با توجه به نتايج حاصل از تجزيه واريانس، اثرات متقابل هيبريد

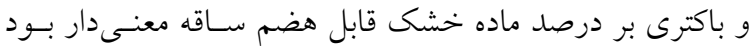
(جدول Y). مقايسه ميانگين اثرات اصلى نشـان داد كـه هيبريـــ بولسون از نظر درصـد مـاده خشـى قابـل هضـم بـا ميـانخين

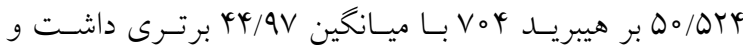
باكترى فلورسنت 199 با داشتن r / / ه درصد ماده خشك قابل

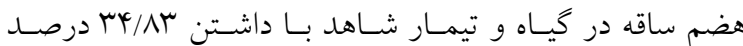
به ترتيب بيشترين و كمترين مقدار را داشتند (جدول r). مقايسه

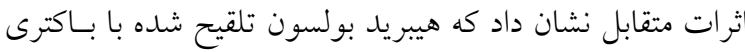

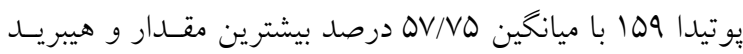

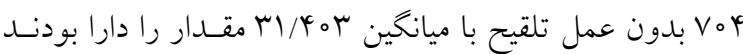

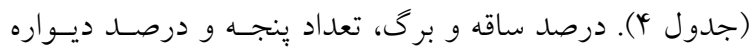
سلولى بر ميزان قابليت هضم ماده خشك مؤثرند (TI). تفـاوت

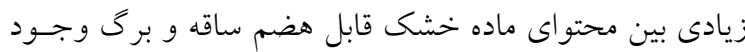

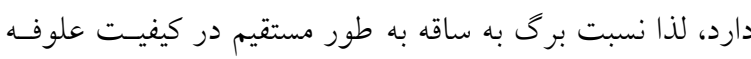

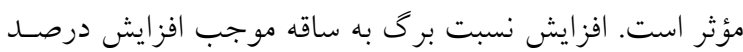

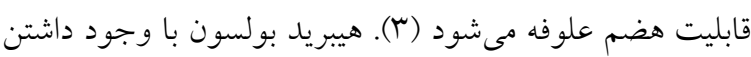

ماده خشك كل با توجه به نتايج حاصل از تجزيه واريانس، اثرات متقابل هيبريد و باكترى بر ماده خشك كل در بوته معنى دار بـود (جــدول ؟). مقايسه ميانخين اثرات اصلى نشان داد كه هيبريد بولسون از نظر

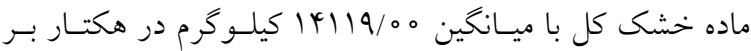

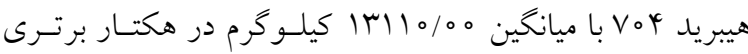

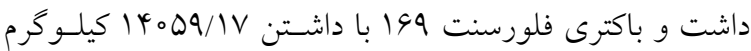

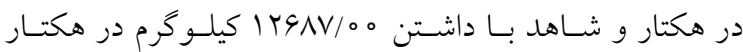

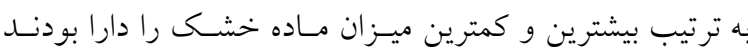
(جدول r). مقايسه اثرات متقابل نشـان داد كـه بيشـترين مـاده

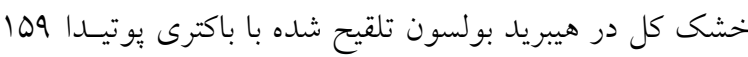

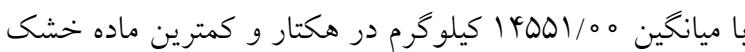

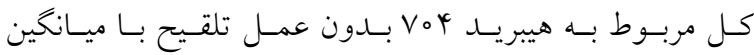

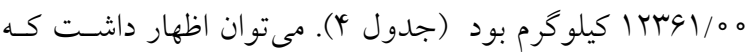

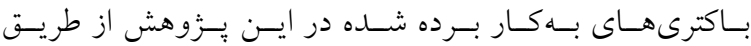
سازو كارهاى توليد مواد تنظيم كننده رشد، مهار عوامل بيمارىزا

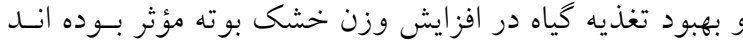
$(T V, T \&$, 10$)$

\section{درصد ماده خشك قابل هضم برى}

براساس نتايج حاصل از تجزيه واريانس، اثرات متقابل هيبر يد و

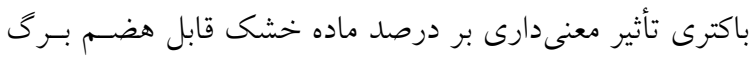

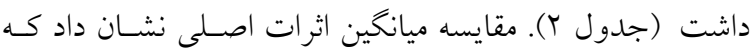
درصد ماده خشك قابل هضم برى بيشتر مربوط به هيبريد Vof

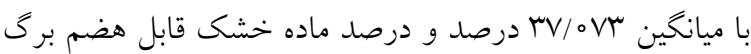

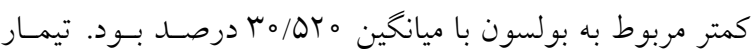

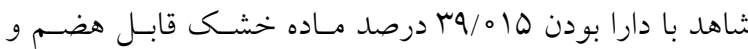
باكترى فلورسنت 199 با داشتن إ/م/ درصد بهترتيب بيشترين

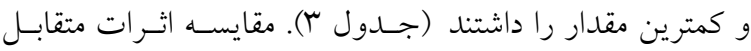
نشان داد كه هيبريد بولسون تلقيح شده با بـاكترى يوتيــا 109

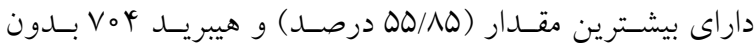

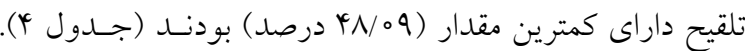




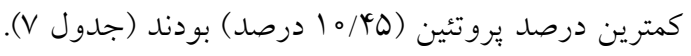
هيبريد بولسون با داشتن تعداد برى بيشتر، درصد يسروتئين بيشترى نيز داشته است. باكترىها ليل تثيـت زيسـتى نيتـروزن

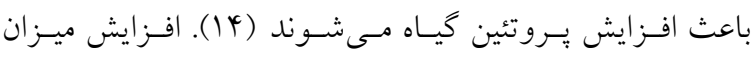
محصسول از طريسق كـاهش نسـبت بـرى بـه سـاقه و افـزايش هيدارت هاى كربن دانه مى تواند علت كـاهش درصـد يــروتئين خام در علوفه تازه باشد. هرجقدر نسبت بـرى بـه سـاقه گيـاه بيشتر باشد ميزان بروتئين خـام نيـز بـالاتر خواهـد بـود (YY) حضور باكترى ها دركنار هيبريد بولسون باعـث افز ايش بيشـتر درصد يروتئين كياه نسبت به عدم تلقيح بـاكترى مسىشـود. در

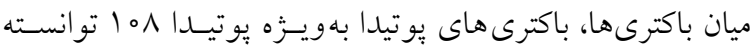
خود را بيشتر با هيبريد بولسون و شرايط محيطى در ارتبـاط بـا افزايش درصد بروتئين كياه تطبيق دهد.

\section{درصد يروتئين خام ساقه}

نتايج تجزيه واريانس بهدسـت آمــده نشـان داد، اثــرات متقابـل هيبريد و باكترى اثر معنى دارى بر درصــ يسروتئين خـام سـاقه داشتند (جدول ه). مقايسه ميانكين اثرات اصـلى نشـان داد كـهـ

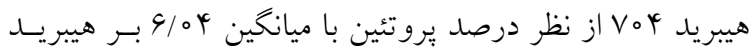
بولسون با ميانحين ه/VY برترى داشت و باكترى فلورسنت 199 با داشتن V/91 درصد بِروتئين در ساقه و تيمار شاهد با داشـتن سآه درصد بـهـ ترتيـب بيشـترين و كمتــرين مقــدار را داشـتند (جدول 9). مقايسه اثرات متقابل نشان داد كه بيشـترين درصــ يروتئين در هيبريد Vof تلقيح شده با باكترى فلورسنت 199 بـا ميانخين N/19 درصد و كمترين درصد يروتئين مربوط به هيبريد بولسون بدون عمل تلقيح با ميانخين / ه درصد بود (جدول V). هر جهه نسبت برگ به ساقه كمتر باشد درصد بروتئين كمتـر است و هم جنين رشد بيشتر ساقه و نزديـك شـدن بـه مرحلـه

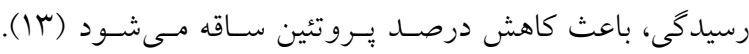
باكترىهاى محرى رشد با تثبيت زيستى نيتروزن باعث افزايش

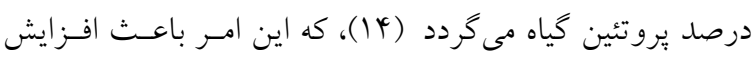

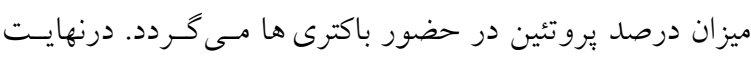

رشد و ارتفاع بيشتر، درصد ماده خشى قابل هضم بالاترى نيـز دارد كه اين امر مىتواند بـهـدليـل خصوصـات زنتيكى هيبريـــ بولسون باشد. باكترىها بهدليل بالا بــردن ميـزان يــروتئين كيـاه باعـث افـزايش قابليـت هضـم مـاده خشـك مسىشـوند (N). بدينترتيب هيبريد بولسون بههمراه باكترى بهويزه باكترى بوتيدا 109 بيشترين درصد ماده خشك قابل هضم را دارد.

\section{درصد ماده خشك قابل هضم بلال}

نتايج حاصل از تجزيـهـ واريـانس نشـان داد كـهـ اثـرات متقابـل هيبريد و باكترى اثر معنى دارى بر درصد ماده خشك قابل هضم بلال داشتند (جدول Y). مقايسه ميانخين اثرات اصلى نشـان داد كه درصد ماده خشك قابل هضم بلال بيشتر مربوط بـه هيبريــ (بود. باكترى فلورسنت 199 بـا دارا بـودن V V درن

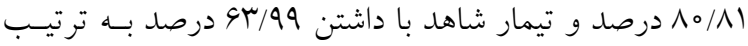
بيشترين و كمترين درصد ماده خشك قابل هضم بلال را بهخود ختصاص دادند (جدول ץ). مقايسه اثرات متقابل نشان داد كـه هم جنين رقم VoY تلقـيح شـده بــا بـاكترى فلورسـنت 199 بـا

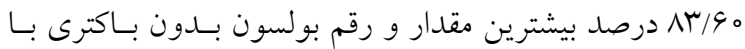
(F/9V

\section{درصد يروتئين خام برى} با توجه به نتايج حاصل از تجزيه واريانس، اثرات متقابل هيبريد و باكترى بر درصد يروتئين خام برگ معنى دار بود (جــدول ه).

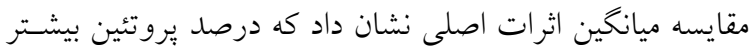

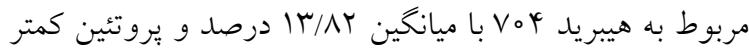
مربوط به هيبريد بولسون با ميانخين 1/99/9 درصد بود. همجنين

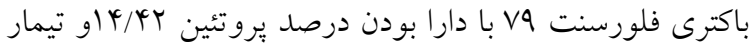
شاهد با داشـتن درصــ يــروتئين سو/ ابـهـ ترتيـب بيشـترين و كمترين درصد يروتئين را به خود اختصاص دادنــ (جــدول 9). مقايسه اثرات متقابل نشان داد كه هيبريد بولسون تلقيح شده بـاــا

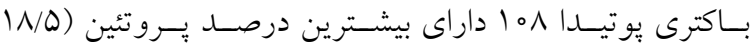
درصد) و هيبريد Vof تلقيح شده با باكترى فلورسنت V9 داراى 
بررسى اثر باكترىهاى محرك رشد بر عملكرد كمى و كيفى ذرت سيلويى

جدول ه. نتايج آناليز واريانس (ميانكين مربعات) مربوط به صفات مورد بررسى

\begin{tabular}{|c|c|c|c|c|c|c|c|}
\hline منهاى همى دلو ديواره سلولى بلال & منهاى همى دلولز ديواره سلولى ساقه & منهاى همى دلود ديواره سلولى لى برى & درصد يروتئين & درصد يروتئين & درصد يروتئين & آزادى درجه & منابع تغييرات \\
\hline$\% / 0 \circ$ & $0 / 01$ & $\circ / 00$ & $0 / 001$ & $V / \circ \circ$ & $\% / 0 \circ$ & r & تكرار \\
\hline$\Gamma / \wedge 9^{* *}$ & MYY//** & $Y I V / N r^{* * *}$ & $\circ / q^{* * *}$ & $0 / 99^{* *}$ & $\Delta / 91^{* *}$ & 1 & هيبريد \\
\hline ( & $\Delta V / I I^{* *}$ & $9 / 94^{* *}$ & $1 / \Gamma_{0}^{* * *}$ & $9 / 1 r^{* * *}$ & ґ/イ*** & tr & باكترى \\
\hline ○/イ** & $\Delta r / 99^{* *}$ & $Y / 9 \Lambda^{* * *}$ & $r / 9 Q^{* *}$ & $\circ / Y Y^{* * *}$ & $1 / 9 \mu^{* * *}$ & r & باكترى ×هيبريد \\
\hline$\%$ & $0 / 01$ & $\%$ & $\%$ & $\%$ & $\%$ & 11 & خطا \\
\hline $1 / 10$ & $r / 9 \circ$ & $T / \Delta D$ & $0 / Y_{0}$ & $0 / Y Y$ & $0 / 14$ & & $(\%) \mathrm{CV}$ \\
\hline
\end{tabular}

هيبريد For با ميانگين rV/F/ درصد نسبت به هيبريد بولسـون با ميانكين درصد ديو اره سلولى منهاى همى سلولز و باكترى يوتيدا 109 بـاــا داشتن ب ب/ سM درصد ديواره سلولى منهاى همى سلولز به ترتيـب بيشترين و كمترين درصد ديواره سلولى منهاى همسى سـلولز را به خود اختصاص دادند (جدول 9). مقايسه اثرات متقابل نشـان داد كه هيبريد fof بدون تلقيح با باكترى داراى بيشترين درصد

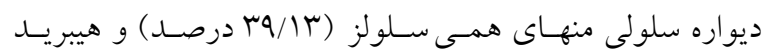
بولسون تلقيح شـده بــا بـاكترى فلورســت V9 داراى كمتـــين



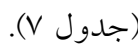

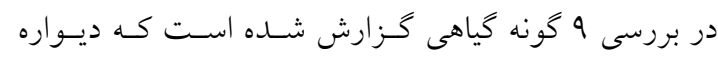
سلولى كياهان مهم ترين عامل تأثير كذار در قابليت هضــم مـاده خشك مى باشد. بالا بودن درصد كل آذين و درصد برى از كـل علوفه توليدى، باعث كاهش درصــ ديـواره سـلولى مسى خـردد

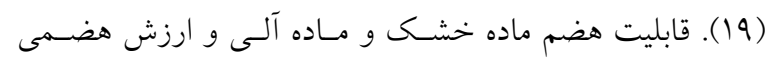
همبستخى بسـيار معنسى دارى را بـا درصسـ ديـواره سـلولى دارا بودند. هيبريد Vof به دليل داشتن تعداد برگ بوته كمتر، درصـد ديواره سلولى بيشترى دارد، زيرا تعداد برى بـا درصـد ديـواره سلولى همبستخى منفى دارد بنـابراين هيبريــد جديــد بولسـون

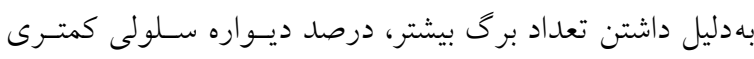

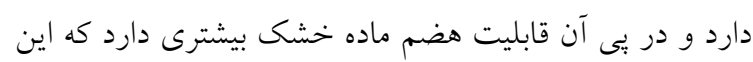

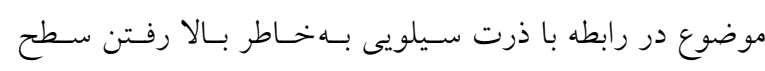

هيبريد Vof به همر اه بـاكترى فلورسـنت 199 بيشـترين درصــ

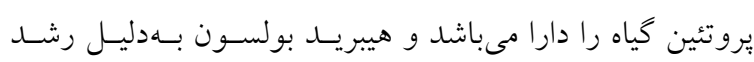
بيشتر و عدم حضور باكترى ها كمترين درصد يـروتئين كيـاه را



درصد يروتئين خام بلال با توجه به نتايج حاصل از تجزيه واريانس، اثرات متقابل هيبريد و باكترى بر درصد بروتئين خام بلال معنى دار بود (جــدول ه).

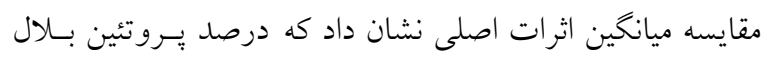

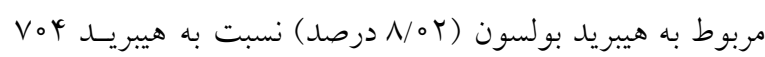

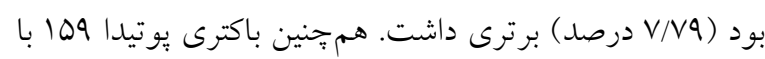

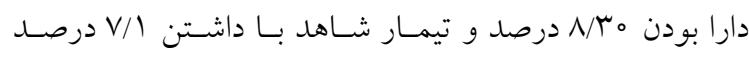
به ترتيب بيشترين و كمترين مقدار را داشتند (جدول 9). مقايسه اثرات متقابل نشان داد كه هيبريد بولسون تلقيح شده با بـاكترى يوتيدا هوا با مقدار ع/9 بيشترين درصد بروتئين و هيبريد

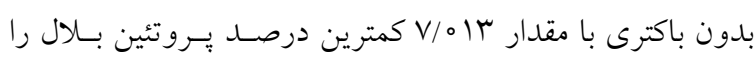

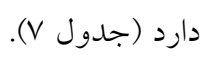

\section{درصد ديواره سلولى منهاى همىسلولز برى}

با توجه به نتايج حاصل از تجزيه واريانس، اثرات متقابل هيبريد و باكترى بر درصد ديـواره سـلولى منهـاى همسى سـلولز بـرى

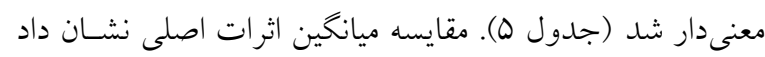
كه درصد ديواره سلولى منهاى همسى سـلولز بيشـتر مربـوط بـهـ 


\begin{tabular}{|c|c|c|c|c|c|c|}
\hline \multicolumn{7}{|c|}{ جدول \&. اثر هيبريد و باكترىهاى محرى رشد بر صفات مورد بررسى گياه ذرت } \\
\hline 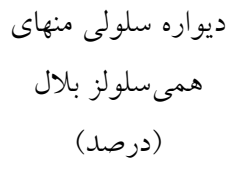 & همى ديواره سلولى منهاى سلو ساقه (درصد) & همى ديواره سلولى منهاى & 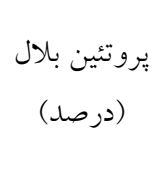 & يروتئين ساقه & يروتئين برى & تيمار \\
\hline rV/GYqa & $\mathrm{rV} / \circ \mathrm{V}^{\mathrm{a}}$ & rV/GYqa & $V / V q^{b}$ & $9 / 04^{4 a}$ & $\mid r / A r^{a}$ & A1 \\
\hline Tr/YYYb & $r_{\circ / \Delta r_{\circ} b}$ & TY/TYY b & $\Lambda / \circ r^{a}$ & $Q / V Y^{4 b}$ & $1 \% / 909 \mathrm{~b}$ & $\mathrm{~A} 2$ \\
\hline$r \Delta / \mu^{4} r_{0} b$ & $r_{\circ} / \Lambda l_{0} d$ & $r \Delta / \mu^{c} \mu_{0} b$ & $\Lambda / \Lambda Y^{b}$ & $V / 9 \Lambda^{\mathrm{a}}$ & $1 \mu / 9 \Delta^{b}$ & B1 \\
\hline$r Y / q \Delta Y^{c}$ & $\mu / \mu^{\epsilon} v_{0} b$ & $r Y / Q \Delta Y^{c}$ & $\Lambda / \circ \Delta^{c}$ & $\Delta / \varphi_{0} b$ & $\mid k / 4 T^{a}$ & B2 \\
\hline$r Y / \Delta q V^{d}$ & $\mathrm{r} / \mathrm{Al} \mathrm{OC}^{\mathrm{c}}$ & $\mu Y / \Delta Q V^{d}$ & $V / 9 Q^{d}$ & $\Delta / \Delta C^{c}$ & $1 \pi / \omega_{0} c$ & B3 \\
\hline Mr/grte & $r T^{\prime} / \Lambda V \Lambda^{c}$ & Mr/grte & $\Lambda / \Gamma_{\circ} a$ & $Q / \Gamma q d$ & $I r / V \Delta^{\mathrm{d}}$ & B4 \\
\hline$r G / r V \mu^{a}$ & $r q / \circ \mid 0^{a}$ & $r G / r V r^{a}$ & $V / 10^{e}$ & Q/Yre & $\mid r / g \mu^{\mathrm{e}}$ & B5 \\
\hline
\end{tabular}

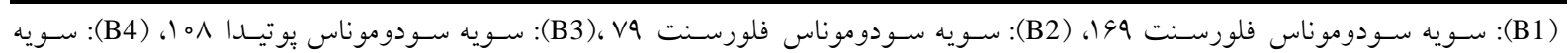

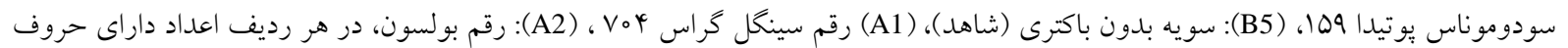

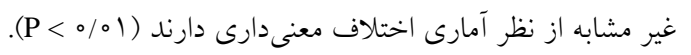

جدول V. مقايسه ميانگين مربوط صفات مورد بررسى گياه ذرت تحت تأثير تيمارهاى به كار برده شده

\begin{tabular}{|c|c|c|c|c|c|c|}
\hline 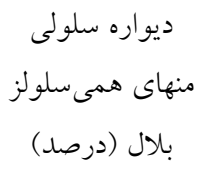 & ديواره سلولى منهاى & 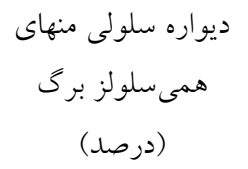 & 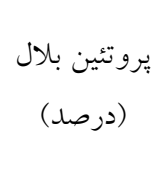 & "ِروتئين ساقه & 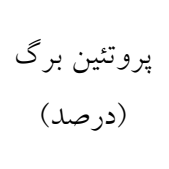 & اثرات متقابل \\
\hline V/TYVi & rV/rGc & $r q / \circ r^{a}$ & $\Lambda / V \mu^{\mathrm{b}}$ & $\Lambda / 1 \varphi^{a}$ & $|F / V|^{a}$ & $\mathrm{~A} 1 \mathrm{~B} 1$ \\
\hline$N / 9 \circ r^{f}$ & rV/ryd & rN/l。b & $V / \mu_{0} c d$ & $\Delta / \Lambda_{\circ} c$ & $|\psi / \Delta|^{\mathrm{b}}$ & $\mathrm{A} 1 \mathrm{~B} 2$ \\
\hline $10 / 11 r^{\mathrm{d}}$ & $M r / Y^{f f}$ & $r V / r I^{c}$ & $\Lambda / V I^{b}$ & o/dre & $1 \% / 9 \Lambda^{d}$ & A1B3 \\
\hline $9 / 9 \vee \mu^{e}$ & $\Gamma_{\Lambda / q^{b}}$ & $M \Psi / 9 \Lambda^{d}$ & $V / Y_{0}$ de & $\Delta / \uparrow \& f$ & $|r / \Delta|^{\mathrm{e}}$ & A1B4 \\
\hline 11/זra & $r q / 10^{a}$ & $r q / 1 r^{a}$ & $V / \circ 1^{e}$ & $Q / T V^{i}$ & $\mid r / r \varphi^{i}$ & A1B5 \\
\hline$\Lambda / \Delta ৭ V^{f}$ & $r Y / r \varphi^{i}$ & $\mathrm{M} / \mathrm{Arg}$ & $V / Q Y^{c}$ & $V / T I^{b}$ & $\mid r / \Delta q^{h}$ & $\mathrm{~A} 2 \mathrm{~B} 1$ \\
\hline$\Lambda / 4 q \vee g$ & $r q / 9 \circ g$ & $r / / \Lambda \circ g$ & $\Lambda / V^{\circ} b$ & $\Delta / Y_{0} \circ g$ & $\mid \psi / \mu_{0} c$ & A2B2 \\
\hline$\Lambda / I r_{0} h$ & & $m / 9 \Lambda^{g}$ & $V / Y_{0} \mathrm{de}$ & $D / \varphi_{0} \mathrm{~d}$ & $1 r / \circ 0^{f}$ & A2B3 \\
\hline $10 / / f_{0} c$ & $r V / r V^{h}$ & $M T / / q_{f}$ & $q / 4 \circ a$ & Q/ & $\mid r / \circ \circ j$ & $\mathrm{~A} 2 \mathrm{~B} 4$ \\
\hline משתמאן & $r N / \mu^{b}$ & & $V / 19 \mathrm{de}$ & $\Delta / 1 q^{j}$ & $1 Y / 9 \circ g$ & A2B5 \\
\hline
\end{tabular}

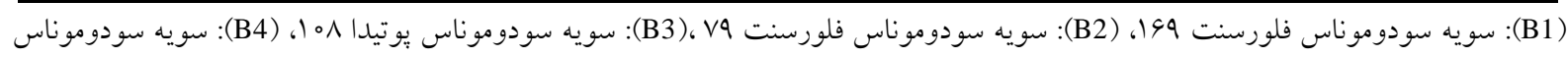
يوتيدا هQ ا، (B55): سويه بدون باكترى (شاهد)، (A1) رقم سينگل كراس V04 ، (A2): رقم بولسون، در هر رديف اعداد داراى حروف غير مشابه از

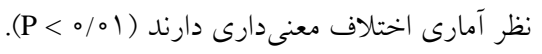




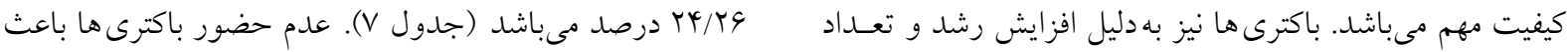

$$
\begin{aligned}
& \text { برگ باعث كاهش درصد ديواره سلولى مى گردند. بدين ترتيـب بالا رفتن درصد ديواره سلولى مىشوند. } \\
& \text { عدم مصرف باكترى و رقم Vof به دليل داشتن تعداد برى كمتر } \\
& \text { درصد ديواره سلولى بيشترى دارند. هيبريد بولسون بدون تلقيح درصد ديواره سلولى منهاى همىسلولز بلال } \\
& \text { با توجه به نتايج تجزيه واريانس، اثرات متقابل هيبريد و باكترى } \\
& \text { تأثير معنى دارى بر درصد ديواره سلولى منهاى همى سلولز بـلال } \\
& \text { با باكترى به دليل نبود حضـور بـاكترى بـراى بـالا بــردن تعـداد } \\
& \text { برگهاى بوته نيز درصد ديواره سلولى بالايى دارد. } \\
& \text { داشتند (جدول ه). مقايسه ميانخين اثرات اصسلى نشـان داد كـه }
\end{aligned}
$$

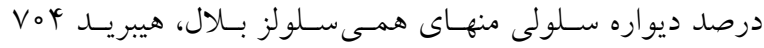

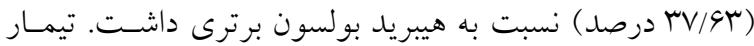

$$
\begin{aligned}
& \text { شاهد با دارا بودن YV/TV درصد و باكترى بوتيدا } 109 \text { با داشتن } \\
& \text { Y Y TM درصد به ترتيب بيشترين و كمترين درصد ديواره سلولى } \\
& \text { منهاى همى سلولز بلال را به خود اختصاص دادنــ (جــدول 9). } \\
& \text { نتايج مقايسه اثرات متقابل نشان داد كه هيبريد Yor بلدون تلقيح }
\end{aligned}
$$



$$
\begin{aligned}
& \text { همىسلولز و هيبريد بولسون تلقيح شده با باكترى فلورسنت V9 }
\end{aligned}
$$

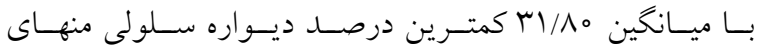

$$
\begin{aligned}
& \text { همىسلولز بلال را دارا بودند (جدول V). } \\
& \text { با توجه به نتايج حاصل از اين بزوهش، كاربرد سـويههـاى } \\
& \text { مناسب و مؤثر باكترىهاى محرى رشد كياه مىتواند در افزايش }
\end{aligned}
$$

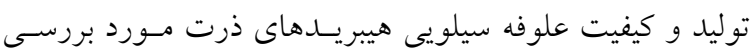

$$
\begin{aligned}
& \text { تحت شرايط اجراى اين آزمايش بسيار مؤثر باشد. }
\end{aligned}
$$

\section{منابع مورد استفاده}

1. Allen, M. F., W. Q. Swenson, J. I. uerejeta, L. M. Egerton-Warburton and K. K. Treasurer. 2003. Ecology of mycorhea: a conceptual framework for complex interactions among plants and fungi. Annual Review of Psychology 41: $271-303$.

2. Annichiarico. P. 1995. Analysis of genotype environment interaction for maize hybrids. Journal of Genetics and Breeding 56: 3-8.

3. Antoun, H. and J. kloepper. 2001. Plant Growth Promotion Rhizobacteria. Academic Press, USA.

4. Asghar, H. N., Z. A. Zaeir and M. Arched. 2004. Screening rhino bacteria for improving the growth, yield and oil content of canola (Brassica napus). Iran Agricultural Research 55: 187- 194. (In Farsi).

5. Chabot, R., H. Antoun and M. P. Cescas. 1993. Stimulation of the growth of maize and lettuce by inorganic phosphorus solubilizing micro-organisms. Microbiology 39: 941-947.

6. Coleman, S. E. and J. E. Moore. 2003. Feed quality and animal performance. Field Crops Research 84: 17- 29.

7. Foruzesh, P., M. Valizadeh, R. Choogan and D. Hasan panah. 1998. Correlation between functionality and yield components in maize hybrids fantastic and very early analysis of causality. MSc. Thesis, Islamic Azad University, Ardebil. (In Farsi).

8. Gholami, A. 2000. Effect of Maycorrhizal fungi on the growth and yield of maize in the region shahrood. MSc. 
Thesis, Tarbiat Modarres University, Tehran. (In Farsi)

9. Glick, B. R., L. Chagping, S. Ghosh and E. Du. Mbroff. 1997. Early development of canola seed lines in the presence of the plant growth promoting rhizobacterium pseudomonas putida GR12-2. Soil Biology and Biochemistry 24(8): 1233-1239.

10. Hamidi, A., A. Ghalavand, M. Dehghanshoar, M. J. Malakooti, A. Asgharzadeh and R. Chokan. 2006. Effects of plant growth promoting rhizobacteria (PGPR) on yield of forage maize. Pajouhesh and Sazandegi 70(1):16-22. (In Farsi).

11. Hernandez, A. N., A. Hernandez and M. Heydrich. 1995. Selection of rhizobacter for use in miaze cultivation. Cultivos Topicales 6: 5-8.

12. Jafari, A., V. Connolly, A. Frolich and E. K. Walsh. 2003. A note on estimation of uality in perennial ryegrass by near infrared spectroscopy. Irish Journal of Agricultural and Food Research 42:293-299.

13. Kephart, K. D., D. R. Buxton and R. R. Hill. 1989. Morphology of alfalfa divergently selected for herbage lignin concentration. Crop Science 29: 293-296.

14. Khavazi, K., H. Asadi Rahmani, M. J. Malakuti. 2005. Necessary for Industrial Production of Biological Fertilizers. Sana, Tehran. (In Farsi).

15. Leoni, L., C. Ambrosia, A. Petrucca and P. Visca. 2002. Transcriptional regulation of pseudo actin synthesis in the plant growth promoting pseudomonas B10. FEMS Microbiology Letters 208: 219- 225.

16. Ma, B. L., K. D. Subedi, D. W. Stewart and L. M. Dwyer. 2006. Dry matter accumulation and silage moisture changes after silking in leafy and dualpurpose corn hybrids. Agronomy Journal 98:922-929.

17. Malakooti, M. J., M. Homaii. 2004. Fertility Arid Areas (Problems and Solutions). Second Edition. Tarbiat Modares University, Tehran. (In Farsi).

18. Martinez - Toledo, M. V., T. de Ia Rubia, J. Moreno and J. Gonzalez- Lopez. 1988. Root exudates of zea mays and production of axons, gibberellins and cy tokenism by Azotobacte rchroococc um . Plant and Soil 110: 149-152.

19. Murphy, W. M., J. Wetch and R. Palmer. 1996. Digestibility of silage made fram corn intercropped white soybean. Dairy Science 67:1532-1534.

20. Reid, R. L., Jung, G. A. and W. V. Thayne. 1988. Relationships between nutritive quality and fiber components of cool season forages: A retrospective study. FEMS Microbiology Letters 66: 1275-1291

21. Rezvani moghadam, P. 1991. Effect of Nitrogen on the nutritive value, yield and growth characteristics of four cultivars of forage sorghum. MSc. Thesis, Ferdowsi University of Mashhad, Mashhad. (In Farsi).

22. Rohitashav-Singh Sood, B. K., V. K. Sharma and R. Singh. 1993. Response of forage maize (Zea mays L.) to azoth obacter inoculation and nitrogen. Indian Journal of Agronomy 38: 555- 558.

23. Sangoi, L. 2000. Understanding plant density effects on maize growth and development and important issue maximize, Grain yield. Ciencia Rural 31: 159-168.

24. Sheperd, A. C. and L. Kung. 1996. Effect of an anzyme additive on composition of corn silage ensiled at various stage of maturity. Dairy Science 79:1767-1773.

25. Wilman, D. and P. Resaving Moghaddam. 1998. In vitro digestibility and neutral detergent fiber and lignin contents of plant parts of nine forage species. The Journal of Agricultural Science 131: 51 - 58.2.

26. Zahir, A. Z., M. Arched and W. F. Franken berger. 2004. Plant growth promoting rhizobacteria: applications and perspectives in agriculture. Advances in Agronomy 81: 97- 168.

27.Zahir, A. Z., M. Arched and A. Khalid. 1998. Improving maize yield by inoculation with plant growth promoting rhizobacteria. Soil Science 15: 7- 11. 


\title{
Effect of Plant Growth-Promoting Bacteria on Quantitative and Qualitative Yield of Forage Maize
}

\author{
R. Abasi ${ }^{*}$, S. A. Siadat ${ }^{2}$, A. Bakhshandeh ${ }^{2}$ and S. Y. Mosavi ${ }^{3}$
}

(Received: May 18-2014; Accepted: June 24-2014)

\begin{abstract}
This research was conducted to investigate the effect of growth-promoting bacteria on yield and some traits of maize. This experiment was performed as a factorial randomized complete block design with three replications at research farm of Islamic Azad University, Izeh branch, Iran. The experimental factors included four strains of plant growth-promoting bacteria: Pseudomonas fluorescent 169 (B1), Pseudomonas fluorescent 79 (B2), Pseudomonas putida 108 (B3), Pseudomonas putida 159 (B4) and without bacteria (control, B5) and two corn varieties namely sc 704 (A1) and Bolson (A2). Before planting corn seeds were soaked with liquid inoculation. Plant height, number of leaves per plant and ear, forage yield, dry matter and dry matter digestibility of leaf, stem and ear, crude protein and cell wall without hemicellulose in the leaf, stem and ear were evaluated. Analysis of variances showed that the effects of varieties, bacteria and their interaction on all traits were significant. Plant height, number of leaves per plant and ear, forage yield, dry matter and stem dry matter digestibility were higher in Bolson. Moreover, dry matter digestibility of leaf and ear, crude protein and cell wall without hemicellulose in the leaf, stem and ear of sc 704 were greater, compared to hybrid Bolson. Plant height, number of leaves per plant and ear, forage yield, dry matter and dry matter digestibility of stem and ear were greater in at the presence of fluorescent strains than those of putida strains. The results revealed that bacterial inoculation enhances the grain yield, yield components and quality of forage maize. Bolson seemed potent to outperform sc 704, though this proposition needs further examination in future field trials.
\end{abstract}

Keywords: Maize, Growth-promoting bacteria, Dry matter digestibility, Yield

\footnotetext{
1, 2. Graduated MSc. Student and Professors, Department of Agronomy, College of Agriculture, Ramin Agriculture and Natural University, Ahvaz, Iran.

3. PhD in Agronomy, Jahad Agricultural Organization of Khuzestan, Ahvaz, Iran.

*. Corresponding Author, Email: Abasiroghayeh@yahoo.com
} 